\title{
Development of domestic tourism in the context of a pandemic
}

\author{
E.G. Efimova ${ }^{1, *}$, N.A. Levochkina ${ }^{2}$, B.E. Khabibullina ${ }^{1}$ \\ ${ }^{1}$ Ural State University of Economics, 8 Marta str. / Narodnaya Volya, Yekaterinburg, Russia \\ ${ }^{2}$ K.G. Razumovsky Moscow State University of Technologies and Management (the First Cossak \\ University), Moscow, st. Zemlyanoyval, 73, Omsk, Kujbysheva Str., 79, Russia
}

\begin{abstract}
Preserving the health of the population occupies a special place at the legislative level, in the socio-economic strategies for the development of regions and the country as a whole. The preservation of human health depends not only on one's own desire to preserve it, including the current state of the state and the development of the country's tourism industry. Recreation and recreation for modern people, who mainly live in cities and megacities characterized by a high level of pollution due to the intensity of economic activity, are of particular importance for maintaining health and life expectancy. An increase in people's life expectancy is considered at the state level as an important indicator of people's well-being, improving the level and quality of life. Russia has created unique conditions and opportunities for the development of domestic tourism, which, with reasonable organization, investments, including the creation of public-private partnerships, and improving the efficiency of services provided, allow us to carry out our activities in the field of preserving and maintaining public health, increasing the duration and quality of life. Domestic Russian tourism can be considered as the basis for the socio-economic development of territories at any level, as well as as an industry whose contribution to the country's GDP can be significant.
\end{abstract}

\section{Introduction}

Recreation and recreation are of particular importance for maintaining health. In Russia, there are a lot of conditions and opportunities to spend holidays, weekends and holidays with health benefits (tours, resorts, weekend sanatoriums, etc.). These types of domestic tourism have the main purpose of their activities prevention and treatment, recreation and rehabilitation of people, which in general allows you to maintain health, maintain working capacity and increase the activity of life. Including domestic tourism for many regions can become the basis for economic growth, the development of transport infrastructure, services and socio-economic development.

\footnotetext{
*Corresponding author: natnaukaomsk@mail.ru
} 


\section{The potential for the development of domestic tourism in Russia}

According to experts, the existing potential for the development of the tourism industry in Russia and its regions remains largely unrealized [18], which is defined as used opportunities or lost benefits in improving the quality of public health. Since 2020, due to the spread of COVID-19, the development of domestic tourism, especially for the purpose of improving health, maintaining the level of health, is of particular importance, and programs for the development of medical and health tourism are the most promising direction. Since 2020, international tourist flows have decreased by 20-30\% [16] and according to the participants of the Russian tourism market, the industry can fully recover no earlier than 2021-2022 [19].

The conditions of the pandemic and the closure of borders can stimulate the development of the potential of tourist and health-improving domestic tourism. In the field of maintaining human health, medical and health tourism is an important type of recreational activity. It is more difficult to cure the disease than to acquire it, so prevention is crucial in maintaining health. A resort is a territory developed and used for therapeutic and preventive purposes with natural therapeutic resources [20], called a resort economy (a complex of therapeutic and preventive institutions [7, p. 2]). The therapeutic properties of natural objects and conditions are established on the basis of scientific research, long-term practice and are approved by the federal executive authority responsible for health issues [20]. According to the World Tourism Organization, treatment and recovery are the main motivations of tourists [5], but experts determine that over the past 15 years, the number of trips for treatment in the world has increased by $10 \%$ [17, p.222].

"Natural, historical, socio-cultural objects that can satisfy the spiritual needs of tourists, promote the restoration and development of their physical strength" [20] are defined in No. 132-Federal Law of November 24, 1996 as natural and recreational resources that positively affect the well-being of people [2]. We found out that most of the existing resort and medical institutions of the Russian Federation are based on the unique natural conditions and resources of the localities (information from the official websites of sanatoriums and resorts of the Russian Federation about their activities and services offered was used). The conducted research revealed problems and some trends in the sphere of sanatorium and resort services. Firstly, if the sanatorium offers services in a low price segment, then, as a rule, they are provided on a morally and physically outdated material and technical base [4]. Obviously, in the medium term, the best dynamics of development will be shown by those organizations that are focused on providing services of a higher quality and complex nature. Another problem is the decline in income of the population [4], including caused by the COVID-19 pandemic, which affects pricing in the industry, where sanatoriums need to develop and offer treatment programs and other types of services with acceptable quality and affordable price.

Currently, the situation with COVID-19 shows that the sanatorium and resort industry remains in an unstable situation and has such problems as: closing organizations, banning or restricting movement, a sharp drop in income and the prospect of a prolonged decline [21]. The absence of tourists during the period of isolation [12], as well as the decline in income of the population caused by the pandemic [4] significantly affects pricing in the industry, where sanatoriums need to develop and offer treatment programs and other types of services with acceptable quality and affordable price. According to surveys, $80-90 \%$ of tourists want to postpone their vacation, since domestic resort facilities that meet or are close to international service standards are much more expensive than foreign ones, and affordable options do not meet expectations [8]. In addition, a serious problem remains attracting customers aged 20-40 years, who, according to experts, have not formed the need 
for annual visits to sanatoriums (a kind of imprint of austerity in the post-Soviet space), and the quality of service and infrastructure of many resorts is simply unattractive for them [11].

Many researchers see difficulties in the organization and development of domestic tourism. D. Toropova highlights the problems with logistics: "If we consider such destinations as Baikal, Altai or Kamchatka, where even Russians dream of getting to, then there are almost no group tours there. Moreover, the cost of a plane ticket is so high that it is cheaper to fly to Europe, " notes the distance of the airports from the sights, which requires the organization of additional transfers and leads to an increase in the cost of tourist products, and therefore does not contribute to the organization of a "mass tourist flow" [18]. Due to high prices and risks, "Russia, as a destination, is not in high demand among the company's customers," A. Pshishylny notes, noting "not friendly booking conditions with Russian contractors" for various reasons [18].

The development of tourism in Russia has not been given due attention for a long time. Nevertheless, it has good prospects for creating a tourist product - attractive and competitive - for which it is necessary to create such conditions that both foreign guests and Russians look at Russian resorts in a new way. "If many countries are still closed, we need to develop domestic tourism, these are obvious things," Russian President Vladimir Putin said [14]. It is obvious that the situation with the pandemic is an excellent opportunity for the development of domestic tourism, especially with competitive conditions.

We believe that the solution of a number of tasks-attracting investment and forming a public-private partnership; developing a national idea and promoting domestic tourism; providing tourist subsidies for low-income people (pensioners, students, etc.); creating a unified register and a system of categorization of tourist business entities, etc. - will allow us to form a high-quality offer, in connection with which Yu. Naumov says: "Give people a high-quality service, show the value of a particular place of rest, and you will never have to call them again, they will go themselves, and tourism in the regions will spread its wings" [15]. It should be noted that the World Travel and Tourism Council (WTTC) concludes in its research: "Industry leaders are using the crisis as an opportunity for further inclusive and sustainable growth of the sector" [1] and, for example, the UN report presents priority areas for tourism transformation after the COVID-19 pandemic [1]. Here are the words of the Mayor of Moscow N. Sergunina noted that the restrictions during the pandemic "form a huge deferred demand", which makes it more attractive for those economic entities in the tourism sector "who will have favorable offers and the best infrastructure, including digital", since the pandemic forces people to adapt "to a new level of digital comfort", which requires increasing competitiveness based on the development and support of technological projects in the tourism industry of the country [3].

We offer the following recommendations for the development of domestic tourism, which can ensure the recovery of the industry after the pandemic (see the table).

Table 1. Recommendations for the development and restoration of the domestic tourism sector in the conditions of the pandemic and the post-pandemic period.

\begin{tabular}{|c|c|}
\hline Recommendation & The essence of the offer \\
\hline $\begin{array}{c}\text { Defining common health } \\
\text { and safety standards }\end{array}$ & $\begin{array}{c}\text { The public and private sectors should jointly agree on the } \\
\text { implementation of occupational safety and health standards in all } \\
\text { sectors of the travel and tourism industry. }\end{array}$ \\
\hline $\begin{array}{c}\text { Strengthening the } \\
\text { employee support system }\end{array}$ & $\begin{array}{c}\text { Ensuring the protection of wages and wage subsidies, as well as } \\
\text { general checks of incentives for consumers and deferral of tax } \\
\text { payments. }\end{array}$ \\
\hline
\end{tabular}




\begin{tabular}{|c|c|}
\hline $\begin{array}{l}\text { Promotion of tourism, } \\
\text { starting with domestic and } \\
\text { regional tourist trips }\end{array}$ & $\begin{array}{l}\text { To benefit from the initial recovery, governments, tourism boards } \\
\text { and organizations should direct their early marketing and advertising } \\
\text { efforts to promote domestic and regional travel; introducing } \\
\text { consumer incentives for travel spending, starting with domestic } \\
\text { travelers and ending with regional and international destinations. }\end{array}$ \\
\hline $\begin{array}{l}\text { Development and } \\
\text { implementation of digital } \\
\text { infrastructure }\end{array}$ & $\begin{array}{l}\text { Investments in the digital infrastructure of new destinations and } \\
\text { remote areas will be crucial, since the needs of the modern traveler } \\
\text { for access to the Internet will be met, as well as improving the } \\
\text { digital skills of staff }\end{array}$ \\
\hline $\begin{array}{l}\text { Development of the } \\
\text { concept of creative spaces }\end{array}$ & $\begin{array}{l}\text { A creative space can be defined as an infrastructure where you can } \\
\text { hold or attend events, find partners, employees, and like-minded } \\
\text { people to implement your ideas, hold creative events, for example, } \\
\text { presentations, concerts, exhibitions, seminars, film screenings with } \\
\text { discussions, etc. [6, pp. 704-707]. The introduction of "creative } \\
\text { spaces" will contribute to the development of environmental } \\
\text { diversity, turning previously poorly presentable areas into centers of } \\
\text { activity. }\end{array}$ \\
\hline $\begin{array}{l}\text { Organizing a business } \\
\text { with a focus on providing } \\
\text { any service as creating an } \\
\text { impression }\end{array}$ & $\begin{array}{l}\text { The impression economy is an approach to the production and } \\
\text { promotion of a product or service based not on satisfying a specific } \\
\text { need, but on creating a positive impression both from the production } \\
\text { and promotion, and from receiving a product or service, as well as } \\
\text { from the subsequent sensations received by the consumer of the } \\
\text { product or service [22]. It is for impressions that a tourist often goes } \\
\text { hundreds and thousands of kilometers away. And impressions are } \\
\text { created precisely by culture: both cultural and historical heritage, } \\
\text { and attractive cultural events }\end{array}$ \\
\hline
\end{tabular}

\section{Conclusion}

In conclusion, we should quote the words of Mathieu De Klerk, partner at Oliver Wyman: "It is absolutely necessary to go beyond the crisis and continue supporting systemic changes in the industry in order to increase its resilience to future shocks and improve its positive socio-economic воздействие» [23]. It should be noted that the authorities of the Russian Federation are developing a regulatory framework to create conditions and support the development of domestic tourism, which is a "colossal basis for increasing the competitiveness" of domestic modern resorts [9;10] and time will tell how these opportunities will be used.

\section{References}

1. COVID-19 analytical note and the transformation of tourism (2020). Access mode: https://www.tohology.com/hospitality/industry/vliyanie-covid-19-na-industriyuturizma-i-gostepriimstva

2. N. I. Borodavkin, A. B. Bushev, Medical and health tourism as a type of recreational activity, Materials of the IX International Student Scientific Conference "Student Scientific Forum" (2017). Access mode: https://scienceforum.ru/2017/article/2017039980

3. Vedomosti "How the coronavirus is changing the world tourism industry" (2020). Access mode: https://www.vedomosti.ru/partner/articles/2020/12/20/851707-antivirusputeshestvii 
4. I. N. Vilkov, Trends in the development of the sanatorium-resort complex of Russia, Moscow Economic Journal (2020). Access mode: https://qje.su/en/ekonomicheskayateoriya/moskovskij-ekonomicheskij-zhurnal-8-2020-2

5. E. L. Dracheva, Special types of tourism. Medical tourism: a textbook for students of higher educational institutions studying in the specialty "Economics and management at the enterprise of tourism and hotel management", 150 (2008)

6. G. V. Zharkov, Are there any sociological indicators of creativity? Scientific and practical conference "VII Kovalev readings" (2012)

7. L. B. Zhuravleva, Textbook on the discipline "Resort business with the basics of balneology" (2008). Access mode: https://www.studmed.ru/view/zhuravleva-lbkurortnoe-delo-s-osnovami-kurortologii 48d162a6dbd.html?page $=1$

8. Will Russian resorts replace Turkey and Greece for tourists (2020). Access mode: https://tourism.interfax.ru/ru/analytics/market overview/70341/

9. Meeting of the Presidium of the State Council on increasing the investment attractiveness of Russian resorts (2016). Access mode: http://kremlin.ru/events/president/news/52769

10. A. N. Razumov, Federal industry Journal for medical and pharmaceutical Workers, 2 (2019). Access mode: http://ktovmedicine.ru/2019/2/

11. Medical bulletin on the problems of the sanatorium and resort industry (2015). Access mode: https://www.vivat-zdorovie.ru/aktsii-i-novosti/intersenaya-statya-meditsinskiyvestnik-pishet-o-problemakh-sanatorno-kurortnoy-otrasli/

12. On the temporary suspension of accommodation in sanatoriums, the work of resort facilities of mass recreation and the activities of public catering organizations (2020) Access mode: http://government.ru/orders/selection/401/39288/

13. Providing support and assistance in coordination for the safe and sustainable recovery of tourism World Tourism Organization (2020). Access mode: https://www.unwto.org/ru/taxonomy/term/356

14. A. Polyanskaya, Forward and upward: domestic tourism will no longer be the same. The new national project will support the industry at the state level (2020). Access mode: $\quad$ https://iz.ru/1035333/aleksandra-polianskaia/vpered-i-vverkh-vnutrenniiturizm-uzhe-ne-budet-prezhnim

15. A. Polyanskaya, Change of scenery: how domestic tourism complements outbound tourism. The demand for tours in Russia is growing steadily (2020). Access mode: https://iz.ru/1023061/aleksandra-polianskaia/smena-dekoratcii-kak-vnutrennii-turizmdopolniaet-vyezdnoi

16. Post-crisis scenarios and the current impact of COVID-19 on the tourism and hospitality industry (2020). Access mode: https://www.tohology.com/hospitality/industry/vliyanie-covid-19-na-industriyuturizma-i-gostepriimstva

17. Problems of tourism studies: a collection of materials of the III International Scientific and Practical Conference of students, postgraduates and young scientists on tourism studies (2014)

18. N. Klyuchevskaya, Tourism-2020 and COVID-19: the tourism industry in the context of the pandemic and after it (2020). Access mode: https://www.garant.ru/article/1376805/

19. Ural hoteliers expect a full recovery of the hotel market no earlier than in a year (2020). Access mode: https://tourism.interfax.ru/ru/news/articles/73314/ 
20. Federal Law No. 132 "On the Basics of Tourist Activity in the Russian Federation" (1996). Electronic access: https://rg.ru/1996/12/03/osnovy-turizma-dok.html

21. E. B. Shtuchnaya, Theory and methodology of sports and health tourism (2005)

22. J. B. Pine, J. H. Gilmore, The Experience Economy: Work is Theatre \& Every Business a Stage, Boston: Harvard Business School Press (1999)

23. WTTC about the future of travel and tourism in the world after COVID (2020). Access mode: https://ru.eturbonews.com/784407/wttc 